\section{Category}

Metal-Catalyzed Asymmetric Synthesis and Stereoselective Reactions

\section{Key words}

\section{zinc}

asymmetric Michael addition

coumarin derivatives

S. K. RAY, P. K. SINGH, N. MOLLETI, V. K. SINGH* (INDIAN INSTITUTE OF TECHNOLOGY KANPUR AND INDIAN INSTITUTE OF SCIENCE EDUCATION AND RESEARCH BHOPAL,

INDIA)

Enantioselective Synthesis of Coumarin Derivatives by PYBOX-DIPH-Zn(II) Complex Catalyzed Michael Reaction J. Org. Chem. 2012, 77, 8802-8808.

\title{
Zink-Catalyzed Synthesis of Coumarin Derivatives by Asymmetric Michael Reaction
}<smiles></smiles>
$\mathrm{X}=\mathrm{O}, \mathrm{NH}, \mathrm{S}$<smiles>CCC1(C)OC(c2cccc(C3=N[C@@H](C(C)C)C(c4ccccc4)(c4ccccc4)O3)n2)=NC1C(C)C</smiles>

up to $99.9 \%$ ee

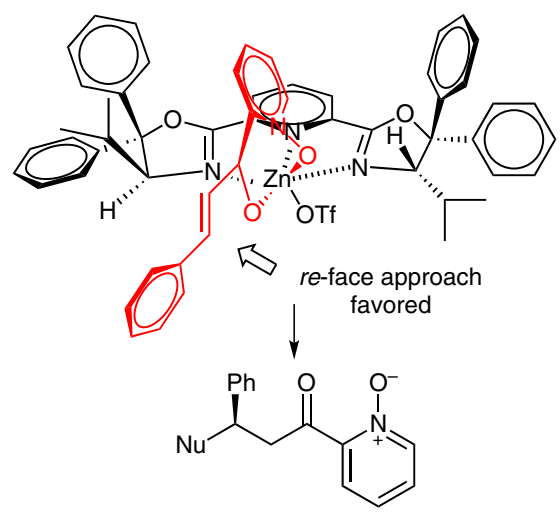

Selected examples:<smiles></smiles>

$\mathrm{R}^{2}=\mathrm{Ph}$ $\mathrm{R}^{2}=2-\mathrm{O}_{2} \mathrm{NC}_{6} \mathrm{H}_{4} \quad 95 \%$ yield, $91 \%$ ee $R^{2}=1-$ Naph $\quad 95 \%$ yield, $53 \%$ ee<smiles>Cn1c(=O)c([C@H](CC(=O)c2cccc[n+]2[O-])c2ccccc2)c(O)c2ccccc21</smiles>

$93 \%$ yield, $97 \%$ ee<smiles>O=C(C[C@H](c1ccccc1)c1c(O)c2cc([N+](=O)[O-])ccc2oc1=O)c1cccc[n+]1[O-]</smiles>

$97 \%$ yield, $85 \%$ ee<smiles>O=C(C[C@H](c1ccccc1)c1c(O)c2ccccc2sc1=O)c1cccc[n+]1[O-]</smiles>

$87 \%$ yield, $70 \%$ ee<smiles>Cc1ccc2oc(=O)c([C@H](CC(=O)c3cccc[n+]3[O-])c3ccccc3)c(O)c2c1</smiles>

$93 \%$ yield, $80 \%$ ee<smiles>Cc1cc(O)c([C@H](CC(=O)c2cccc[n+]2[O-])c2ccccc2)c(=O)o1</smiles>

$90 \%$ yield, $96 \%$ ee
Significance: Coumarin derivatives are a broad class of biological interesting molecules. The zinccatalyzed system presented provides an efficient access to the direct precursors of such compounds with excellent yield (up to 99\%) and enantioselectivity (up to 97\%).

SYNFACTS Contributors: Hisashi Yamamoto, Lan Luo Synfacts 2013, 9(1), 0076 Published online: 17.12.2012 Dol: 10.1055/s-0032-1317844; Reg-No.: H16312SF
Comment: The authors report a PYBOX-DIPH$\mathrm{Zn}$ (II) catalyzed asymmetric Michael reaction and its successful application in the synthesis of coumarin derivatives. This method can tolerate a wide range of cyclic 1,3-dicarbonyl compounds. The resulting products can be easily converted into bioactive molecules such as warfarin and acenocoumarol without loss of enantiopurity. 